\title{
Using annual body size fluctuations to explore potential causes for the decline in a nesting population of the loggerhead turtle Caretta caretta at Senri Beach, Japan
}

\author{
Hideo Hatase ${ }^{1, *}$, Kiyoshi Goto $^{2}$, Katsufumi Sato ${ }^{1, * *}$, Takeharu Bando $^{1, * * *}$, \\ Yoshimasa Matsuzawa ${ }^{1, * * * *}$, Wataru Sakamoto ${ }^{1}$ \\ ${ }^{1}$ Laboratory of Fisheries and Environmental Oceanography, Graduate School of Agriculture, Kyoto University, Sakyo, Kyoto 606-8502, Japan \\ ${ }^{2}$ Minabe Sea Turtle Research Group, 278 Higashiyoshida, Minabe, Wakayama 645-0001, Japan
}

\begin{abstract}
The annual recruitment dynamics and body size fluctuations in adult female loggerhead turtles Caretta caretta nesting on Senri Beach in Minabe, Japan from 1990 to 2001 were investigated along with the number of nests, so that the causes for the recent population decline could be assessed. The number of nests decreased from 335 in 1990 to 29 in 1998, and slightly increased thereafter. The recruit percentage (i. e. the percentage of recruits out of total identified females in each year) varied from 39 to $75 \%$. The lack of a significant correlation between the rates of change in the recruit percentage and in the number of nests suggested that the population decline had been caused by factors affecting both recruits and remigrants. The mean straight carapace length (SCL) varied from 825 to $855 \mathrm{~mm}$. The significant negative correlation between the rates of change in the mean SCL and in the number of nests suggested that the decline had been caused by the decrease in the number of small females. The lack of a significant difference in SCL between recruits and remigrants supported the above scenarios. Since small females tend to inhabit the pelagic Pacific irrespective of their recruit or remigrant status, we proposed that the population decline at Senri Beach was attributable to factors operating in the pelagic waters, such as incidental mortality by longline fisheries.
\end{abstract}

KEY WORDS: Loggerhead turtle $\cdot$ Caretta caretta $\cdot$ Nesting population decline $\cdot$ Body size $\cdot$ Recruitment $\cdot$ Senri Beach . Japan

Resale or republication not permitted without written consent of the publisher

*Email: hatase@kais.kyoto-u.ac.jp

Present addresses:

${ }^{* *}$ National Institute of Polar Research, 1-9-10 Kaga, Itabashi, Tokyo 173-8515, Japan

${ }^{* * *}$ Institute of Cetacean Research, 4-18 Toyomi, Chuo, Tokyo 104-0055, Japan

${ }^{* * * *}$ Sea Turtle Association of Japan, 5-17-18-302 Nagaomotomachi, Hirakata, Osaka 573-0163, Japan
In the North Pacific, the Japanese Archipelago is the largest nesting ground for the loggerhead sea turtle Caretta caretta (Nishimura 1967, Uchida \& Nishiwaki 1982, Kikukawa et al. 1999). However, the number of nests (i.e. the number of nesting females) has rapidly been declining at several Japanese loggerhead nesting sites since 1990 (e.g. Sato et al. 1997) owing to a still unknown cause. It is therefore essential to assess the potential causes of this population decline for effective management and conservation of this endangered species.

Loggerhead turtles hatching on Japanese beaches undertake developmental migrations in the North Pacific Gyre, and some turtles reach the vicinity of Baja California in the eastern Pacific (Bowen et al. 1995). As they grow, they return and recruit to feeding grounds around Japan. After reaching sexual maturity at each feeding ground, adult females undertake seasonal migrations between the feeding grounds and the same nesting beaches every few years (Iwamoto et al. 1985, Dodd 1988, Kamezaki et al. 1997, Miller 1997, Sato et al. 1997). According to Kamezaki et al. (1997), out of 2219 females tagged at 16 nesting sites in the Japanese Archipelago, only 5 individuals relocated their nesting sites. Because of this high nest-site fidelity, a nesting population in any given year consists of recruits and remigrants; recruits are turtles that return to breed for the first time after the developmental migration, while remigrants are turtles that return to the colony after the seasonal migration. Fluctuations in these percentages may be used to infer the causes for the population decline. For instance, if the recruit percentage (i.e. the percentage of recruits out of total identified females in each year) decreases along with the number of nests, 
the decline would be suggestive of a decrease in immature turtles (eggs, hatchlings, juveniles and/or subadults). Otherwise, the population decline would be likely caused by the concurrent decrease in immature turtles and mature turtles (remigrants).

Furthermore, size-related differences in the use of feeding habitats among adult Japanese female loggerheads have been reported (Hatase et al. 2002b). Interestingly, during the non-reproductive season, irrespective of their recruit or remigrant status, small females (straight carapace length [SCL] mean $\pm \mathrm{SD}, 805 \pm$ $32 \mathrm{~mm}$; range 760 to $902 \mathrm{~mm} ; \mathrm{n}=35$; stable carbon and nitrogen isotope ratios $\left[\delta^{13} \mathrm{C}\right.$ and $\left.\delta^{15} \mathrm{~N}\right]$ of egg yolks from these females were $\leq-18$ and $<12 \%$, respectively) tend to inhabit pelagic waters (the pelagic Pacific, seafloor depth $\geq 1000 \mathrm{~m}$ ), whereas large females (SCL $864 \pm 44 \mathrm{~mm}$; range 741 to $968 \mathrm{~mm} ; \mathrm{n}=$ 114; egg yolk $\delta^{13} \mathrm{C}$ and $\delta^{15} \mathrm{~N}$ from these females had values different from those of the small females) inhabit neritic waters (such as the continental shelf in the East China Sea and coastal waters of Japan, seafloor depth $<200 \mathrm{~m}$ ). Based on these findings, we can hypothesize a cause for the population decline. If
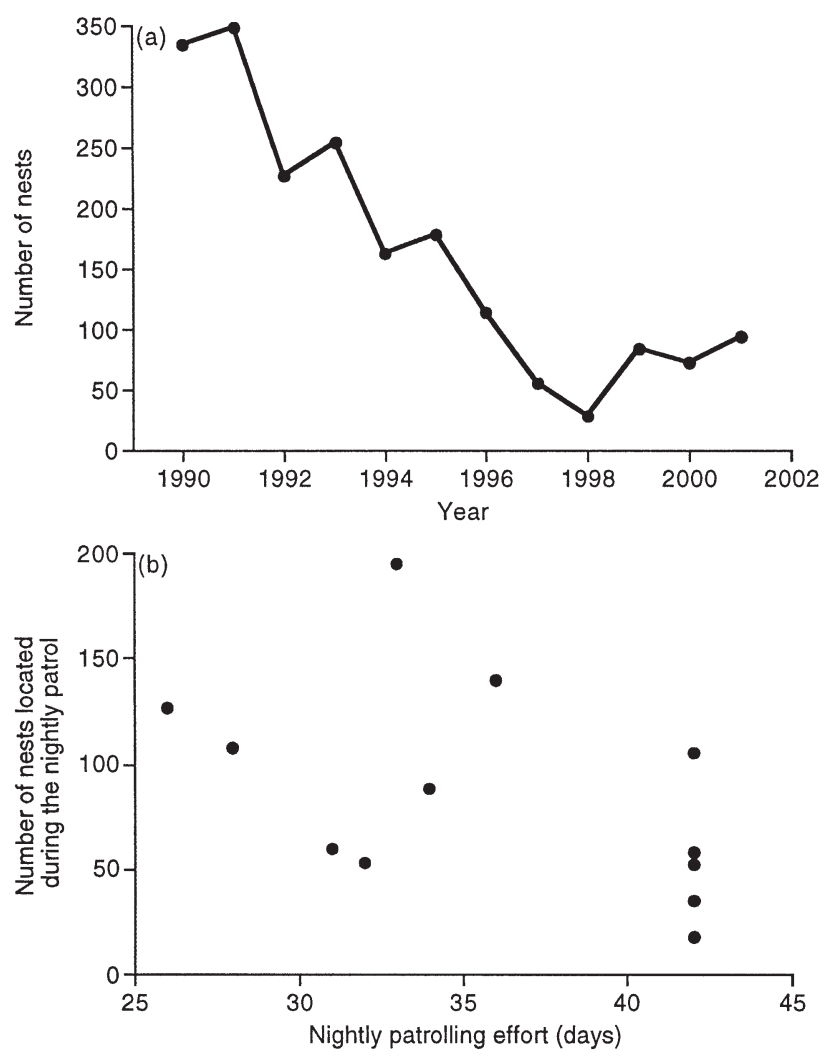

Fig. 1. Caretta caretta. (a) Number of loggerhead turtle nests from 1990 to 2001 at Senri Beach in Minabe, Wakayama, Japan. (b) Relationship between the nightly patrolling effort and the number of nests located during the nightly patrol the mechanism responsible for the population decline operates in the neritic waters, the mean body size of females nesting on Japanese beaches would be expected to decrease. Conversely, if the mortality source occurs in the pelagic waters, the mean body size would be expected to increase.

To assess the causes for the nesting population decline, we investigated the annual recruitment dynamics and body size fluctuations in breeding female loggerheads, in conjunction with an analysis of the number of nests on a Japanese beach from 1990 to 2001.

Materials and methods. Daytime and nightly patrols were conducted on foot at Senri Beach $(1.4 \mathrm{~km}$ in length) in Minabe $\left(33^{\circ} 46^{\prime} \mathrm{N}, 135^{\circ} 18^{\prime} \mathrm{E}\right)$, Wakayama Prefecture, Japan from 1990 to 2001. The procedures for counting nests, identifying turtles and measuring body sizes followed those of Sato et al. (1997). Daytime patrols were conducted throughout the nesting season (May to August) and the daily number of nests was determined by counting new nests with emergence tracks. Nightly patrols were conducted mainly during July, the peak of the nesting season, although incomplete patrols surveyed the beach during other months. Patrols were conducted every night from between 19:30 and 20:30 to $04: 00 \mathrm{~h}$, passing each point on the beach at least once every hour to survey landing turtles. In addition, to test whether the nightly patrolling effort was related to annual fluctuations in the number of nests, the relationship between the period of nightly patrols and the number of nests located during the patrol was examined.

During or after laying eggs, females were identified by tagging on either one or both front flippers or, if they had already been tagged, checking existing tags and tag scars. Therefore, newly tagged females without tag scars were considered as recruits, whereas females with tag scars and tags were considered as remigrants. The SCL of each turtle was measured using calipers with a scale in $\mathrm{mm}$. The same individuals were measured several times in a season to assess the precision of measurement, which was $\pm 3.5 \mathrm{~mm}$.

To understand how the recruit percentage and SCL distribution in the nesting population changed along with the number of nests, we calculated the rates of change in the number of nests, the recruit percentage and the mean SCL $\left(\% \mathrm{yr}^{-1}\right)$, and investigated the statistical relationships between these indices. The rate of change (\%) was calculated as $\left[\left(X_{t}-X_{t-1}\right) / X_{t-1}\right] \times 100$, where $X$ is either the number of nests, the recruit percentage or the mean SCL, and $t$ is the year.

We examined how the rates of change in the recruit percentage and in the mean SCL were related with that in the number of nests. We also performed a 2-way analysis of variance (ANOVA) to test the effects of recruit/remigrant group and year on SCL. 


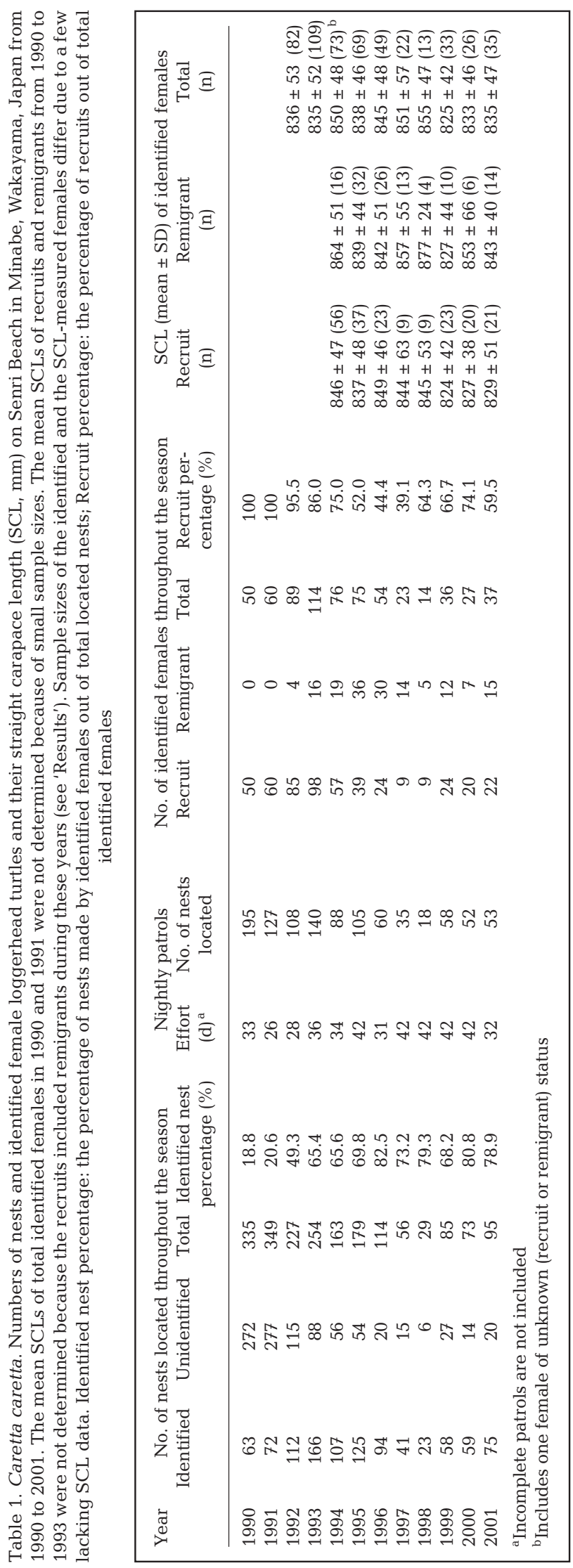

Results. The number of nests rapidly decreased from 335 in 1990 to 29 in 1998, and slightly increased to between 73 and 95 from 1999 to 2001 (Fig. 1a, Table 1). Since there was no significant correlation between the nightly patrolling effort and the number of nests located during the patrol $(\mathrm{r}=-0.49, \mathrm{n}=12, \mathrm{p}=0.11$; Fig. 1b, Table 1), the trends in the number of nests were not attributable to biases in the patrolling effort. Some females nested more than once during the reproductive season. The identified nest percentage (i.e. the ratio of nests made by identified females to total located nests throughout the season) was 49 to $83 \%$ from 1992 to 2001 (Table 1). Thus, the sample size of identified females during these years was large enough to represent the nesting population of each year. The low percentages in 1990 and 1991 (19 and $21 \%$, respectively) are attributable to the lack of tagged turtles before 1990, such that the number of new and untagged turtles was so large that it was impossible to mark all nesting turtles.

The recruit percentage gradually decreased from $100 \%$ in 1990 to $86 \%$ in 1993 , then remained between 39 and $75 \%$ from 1994 to 2001 (Fig. 2a, Table 1). This
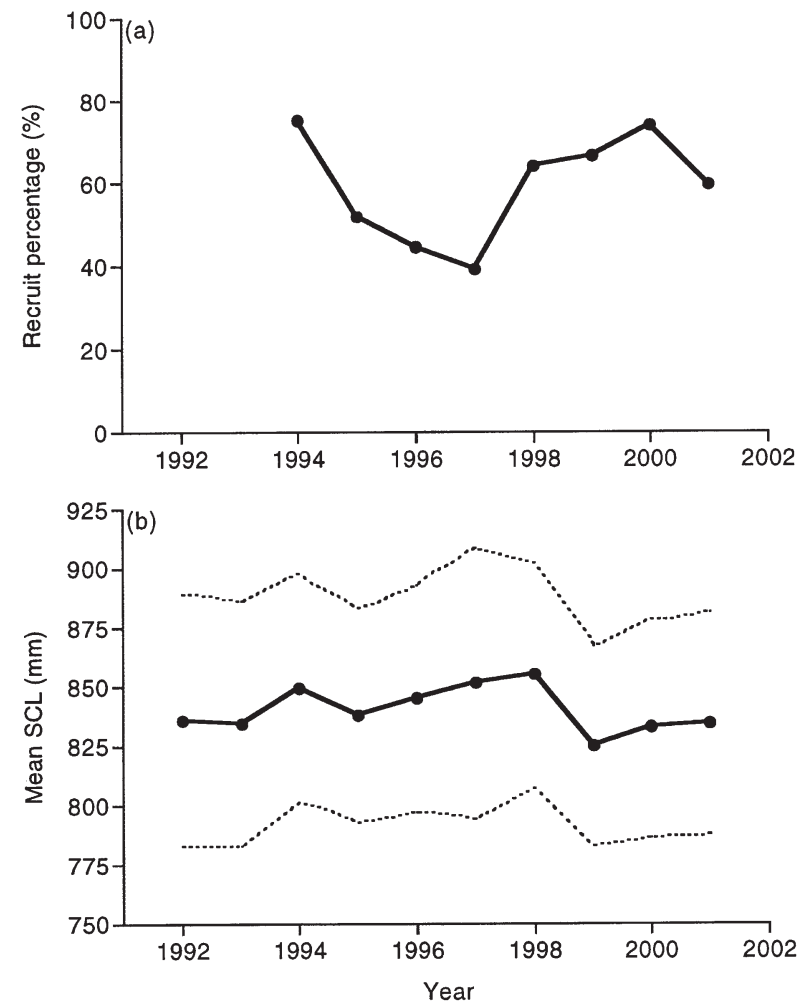

Fig. 2. Caretta caretta. (a) Recruit percentage for identified female loggerhead turtles and (b) their mean straight carapace length (SCL; the solid line) with SD (broken lines), from 1992 to 2001 at Senri Beach in Minabe, Wakayama, Japan. Recruit percentages in 1992 and 1993 were excluded because during these years turtles regarded as recruits included remigrants (see 'Results') 
pattern was likely related to the lack of tagged turtles before 1990, with tagged turtles gradually remigrating in subsequent years. Since most females remigrated within 4 yr (mode: 2 yr) at Senri Beach (cf. Sato et al. 1997), it was unlikely that turtles regarded as recruits from 1994 to 2001 included remigrants. Hence, the recruit percentages during these years were used in the following analyses. There was no significant correlation between the rates of change in the recruit percentage and in the number of nests $(\mathrm{r}=-0.14, \mathrm{n}=7$, $\mathrm{p}=0.77$; Fig. 3a). The mean SCL varied from 825 to $855 \mathrm{~mm}$ from 1992 to 2001 (Fig. 2b, Table 1). There was a highly significant negative correlation between the rates of change in the mean SCL and in the number of nests $(\mathrm{r}=-0.89, \mathrm{n}=9, \mathrm{p}<0.0005$; Fig. $3 \mathrm{~b})$. In addition, there were no significant differences in SCL between recruits and remigrants or among years from 1994 to 2001 (2-way ANOVA: $p=0.06$ for recruit/remigrant group, $\mathrm{p}=0.16$ for year, $\mathrm{p}=0.81$ for interaction; Table 1).

Discussion. There are no documented threats against nesting loggerheads on Senri Beach (e.g. attacks by predators, disturbance by human activity). Addition-
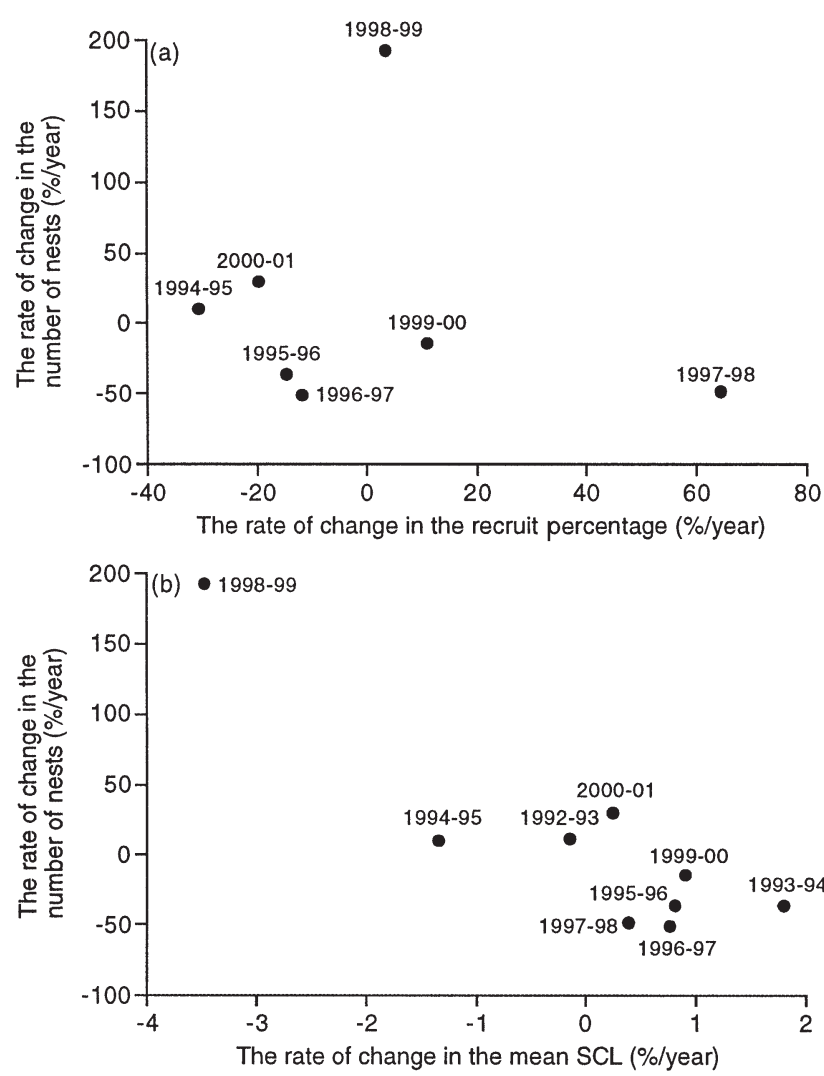

Fig. 3. Caretta caretta. (a) Relationships between the rates of change in the recruit percentage for identified female loggerhead turtles and in the number of nests, and (b) between the rates of change in the mean straight carapace length (SCL) and in the number of nests. Values are identified by year ally, there has been no decline in the hatching success of clutches on the beach during the critical period of the decline in the nesting population (1996 to 2000; Goto 2000). Thus, the population decline at Senri Beach was most likely caused by factors operating at sea, not on land. Further, since loggerhead strandings are very rare at Senri Beach and have not increased during the past decade (K. Goto unpubl. data), the decline was probably not caused by coastal fisheries operating close to shore.

The lack of a significant correlation between the rates of change in the recruit percentage and in the number of nests suggests that the nesting population decline was caused by factors affecting both recruits and remigrants. The significant negative correlation between the rates of change in the mean SCL and in the number of nests suggests that the nesting population decline coincided with a decrease in the number of smaller females. The lack of a significant difference in SCL between recruits and remigrants supports these scenarios. Irrespective of their recruit or remigrant status, during the non-reproductive season, small Japanese female loggerheads inhabit pelagic waters, whereas the larger females inhabit neritic waters (Hatase et al. 2002b). We would not expect loggerhead turtles to change their feeding habitats during the reproductive stage, because females grow little after reaching sexual maturity (Hughes 1974, Bjorndal et al. 1983, Limpus 1985; at Minabe, their growth rate is $1.7 \mathrm{~mm} \mathrm{yr}^{-1} \mathrm{SCL}, \mathrm{T}$. Bando unpubl. data). We therefore propose that the population decline at Senri Beach is attributable to factors operating in the pelagic environment. Although a density-dependent effect on somatic growth rates in an immature green turtle, Chelonia mydas, population has been reported (Bjorndal et al. 2000), there are no such reports for any loggerhead turtle population at present. Moreover, even if this Senri Beach population had responded to the decline through density-dependent effects on growth rates and size at maturity, such results would not have become apparent within this short period. We thus assume that growth rates and size at maturity in this population were invariant during the years we surveyed.

What factors may be impacting turtles in their pelagic habitat? The pelagic waters used by small females (25 to $45^{\circ} \mathrm{N}, 130$ to $170^{\circ} \mathrm{E}$; Baba et al. 1992, 1993, Japan Fisheries Resource Conservation Association 1999, Hatase et al. 2002b) overlap with international longline fishing grounds for tuna and swordfish (US National Marine Fisheries Service 2001). Incidental catches by this fishery may have affected the survivorship of small females, although few data on this potential impact are available except for those of the US. According to the US data, annual estimated takes 
and mortality of loggerheads (whose size distribution is unknown) by the Hawaii-based longline fishery operating in 5 to $40^{\circ} \mathrm{N}$ and 140 to $180^{\circ} \mathrm{W}$ from 1994 to 1999 (fishing effort: 12 to 19 million hooks) were 369 to 501 and 64 to 88 individuals, respectively (US National Marine Fisheries Service 2001). The annual estimates of the international longline fishing effort in the pelagic waters used by small females from 1990 to 2000 were 26 to 48 million hooks (Public Domain Catch \& Effort data aggregated by $5^{\circ} \times 5^{\circ}$, Oceanic Fisheries Programme of the Secretariat of the Pacific Community: www.spc.org.nc/oceanfish/html/sctb/data/index.asp). Assuming that the rates of incidental takes and mortality for loggerheads by these fisheries in the area were the same as those by the Hawaii-based longline fishery, we can roughly estimate the annual incidental takes and mortality of loggerheads there from 1990 to 2000 to be about 800 to 1266 and 139 to 222 individuals, respectively. Small females inhabiting the area would have been included in these turtles. On the other hand, there is no reliable data on turtle bycatch by gillnet, set net and trawl fisheries in coastal waters of Japan and the East China Sea. However, if these fisheries had caused the nesting population decline, the mean SCL of nesting females would have become smaller with the decrease in the number of large females inhabiting the neritic waters. Until 1992, driftnet fisheries had operated extensively across the North Pacific (25 to $45^{\circ} \mathrm{N}, 140^{\circ} \mathrm{E}$ to $150^{\circ} \mathrm{W}$; Wetherall et al. 1993), which is the developmental habitat for immature Japanese loggerheads (Bowen et al. 1995, Hatase et al. 2002a). Around 1000 to 5000 turtles (mostly juveniles and subadults) were estimated to be killed annually by these fisheries (Wetherall et al. 1993). This mortality might also have contributed to the population decline; Crouse et al. (1987) and Crowder et al. (1994) concluded from sensitivity analyses on stage-based population models that population growth was most sensitive to the survival of large juveniles. Finally, the increase in the number of recruits since 1999 might have resulted from the moratorium in the driftnet fishing operation since 1993.

Additional research must address whether patterns similar to the ones we have documented are observed at other Japanese nesting sites where population declines have been reported. Although, in this study, turtle bycatch in pelagic fisheries was suggested as one of the potential causes for the population decline, the actual state of turtle bycatch around Japan should also be investigated quantitatively, e.g. by fisheries observer programs. Thereby, the causes for the decline in Japanese loggerhead nesting populations will be elucidated.

Acknowledgements. We thank H. Tanaka, S. Minamikawa, T. Kurihara, T. Hanaoka, M. Sonoda, A. Nishii, F. Fukuhara, K.
Tamai, H. Kojima, K. Tokunaga, N. Shiba, T. Yasuda and numerous volunteers for helping with nightly patrols on Senri Beach. We also thank the Sea Turtle Association of Japan for supplying tags, tagging pliers and calipers. Anonymous referees critically read this manuscript and provided helpful comments. This work was partly supported by grants from the Research Fellowships of the Japan Society for the Promotion of Science (JSPS) for Young Scientists (H.H., K.S. and Y.M.) and the Ministry of Education, Culture, Sports, Science and Technology (No. 05454093).

\section{LITERATURE CITED}

Baba N, Kiyota M, Suganuma H, Tachikawa H (1992) Research on migratory routes of loggerhead turtles and green turtles by the Argos system. Report on data analysis by scientific observers aboard fishing vessels in 1991. Fisheries Agency of Japan, Tokyo, p 100-106 (in Japanese)

Baba N, Kiyota M, Suganuma H, Tachikawa H (1993) Research on migratory routes of loggerhead turtles and green turtles by the Argos system. Report on data analysis by scientific observers aboard fishing vessels in 1992. Fisheries Agency of Japan, Tokyo, p 86-99 (in Japanese)

Bjorndal KA, Meylan AB, Turner BJ (1983) Sea turtles nesting at Melbourne Beach, Florida, I. Size, growth and reproductive biology. Biol Conserv 26:65-77

Bjorndal KA, Bolten AB, Chaloupka MY (2000) Green turtle somatic growth model: evidence for density dependence. Ecol Appl 10:269-282

Bowen BW, Abreu-Grobois FA, Balazs GH, Kamezaki N, Limpus CJ, Ferl RJ (1995) Trans-Pacific migrations of the loggerhead turtle (Caretta caretta) demonstrated with mitochondrial DNA markers. Proc Natl Acad Sci USA 92: 3731-3734

Crouse DT, Crowder LB, Caswell H (1987) A stage-based population model for loggerhead sea turtles and implications for conservation. Ecology 68:1412-1423

Crowder LB, Crouse DT, Heppell SS, Martin TH (1994) Predicting the impact of turtle excluder devices on loggerhead sea turtle populations. Ecol Appl 4:437-445

Dodd CK Jr (1988) Synopsis of the biological data on the loggerhead sea turtle Caretta caretta (Linnaeus 1758). Biol Rep US Fish Wildl Serv 88:1-110

Goto K (2000) Observations on sea turtles at Senri Beach, Minabe in 2000. Minabe Sea Turtle Research Group, Wakayama (in Japanese)

Hatase H, Kinoshita M, Bando T, Kamezaki N and 7 others (2002a) Population structure of loggerhead turtles, Caretta caretta, nesting in Japan: bottlenecks on the Pacific population. Mar Biol 141:299-305

Hatase H, Takai N, Matsuzawa Y, Sakamoto W, Omuta K, Goto K, Arai N, Fujiwara T (2002b) Size-related differences in feeding habitat use of adult female loggerhead turtles Caretta caretta around Japan determined by stable isotope analyses and satellite telemetry. Mar Ecol Prog Ser 233:273-281

Hughes GR (1974) The sea turtles of South-East Africa II. The biology of the Tongaland loggerhead turtle Caretta caretta L. with comments on the leatherback turtle Dermochelys coriacea L. and the green turtle Chelonia mydas L. in the study region. Report no. 36. South African Association for Marine Biological Research, Oceanographic Research Institute, Durban

Iwamoto T, Ishii M, Nakashima Y, Takeshita H, Itoh A (1985) Nesting cycles and migrations of the loggerhead sea turtle in Miyazaki, Japan. Jpn J Ecol 35:505-511 
Japan Fisheries Resource Conservation Association (1999) Research on migratory routes and diving ecology of sea turtles. Report on conservation research of aquatic animals in 1994-1998, Vol 1. Japan Fisheries Resource Conservation Association, Tokyo, p 1-90 (in Japanese)

Kamezaki N, Miyawaki I, Suganuma H, Omuta K and 7 others (1997) Post-nesting migration of Japanese loggerhead turtle, Caretta caretta. Wildl Conserv Jpn 3:29-39 (in Japanese with English abstract)

Kikukawa A, Kamezaki N, Ota H (1999) Current status of the sea turtles nesting on Okinawajima and adjacent islands of the central Ryukyus, Japan. Biol Conserv 87: 149-153

Limpus CJ (1985) A study of the loggerhead sea turtle, Caretta caretta, in eastern Australia. PhD dissertation, University of Queensland, St Lucia

Miller JD (1997) Reproduction in sea turtles. In: Lutz PL, Musick JA (eds) The biology of sea turtles. CRC Press, Boca Raton, FL, p 51-81

Editorial responsibility: Otto Kinne (Editor),

Oldendorf/Luhe, Germany
Nishimura S (1967) The loggerhead turtles in Japan and neighboring waters (Testudinata: Cheloniidae). Publ Seto Mar Biol Lab 15:19-35

Sato K, Bando T, Matsuzawa Y, Tanaka H, Sakamoto W, Minamikawa S, Goto K (1997) Decline of the loggerhead turtle, Caretta caretta, nesting on Senri Beach in Minabe, Wakayama, Japan. Chelonian Conserv Biol 2:600-603

Uchida I, Nishiwaki M (1982) Sea turtles in the waters adjacent to Japan. In: Bjorndal KA (ed) Biology and conservation of sea turtles. Smithsonian Institution Press, Washington, DC, p 317-319

US National Marine Fisheries Service (2001) Pelagic fisheries of the western Pacific Region, a fishery management plan of the final environmental impact statement. NOAANMFS-SWR, Honolulu

Wetherall JA, Balazs GH, Tokunaga RA, Yong MYY (1993) Bycatch of marine turtles in North Pacific high-seas driftnet fisheries and impacts on the stocks. Bull Int N Pac Fish Comm 53:519-538

Submitted: January 16, 2002; Accepted: September 10, 2002 Proofs received from author(s): November 18, 2002 